\title{
MINAT MELANJUTKAN STUDI PERGURUAN TINGGI SISWA SMKN KOTA SEMARANG
}

\author{
Khasan Setiaji1, Desy Rachmawati² \\ 1. Economic Education Program, Faculty of Economics, State University Malang \\ 2. Economic Education Program, Faculty of Economics, State University Malang \\ setiaji@mail.unnes.ac.id, desy.rachmawati53@yahoo.co.id
}

\begin{abstract}
The existing data shows that the average number of the graduates of SMK Negeri in Semarang City who continued their study to universities was as many as $16.5 \%$. It shows that the graduates' interest in continuing study to universities has not achieved the Minimum Service Standards (SPM) of SMK which states that among 20\% of SMK graduates should continue their study to accredited universities. By this finding, this study was aimed at knowing the influence of the socio-economic background and students' self-potential towards the interest of continuing study to universities in the Eleventh graders of SMK Negeri in Semarang City either simultaneously or partially. The population in this study were the Eleventh graders of SMK Negeri in Semarang City, namely 5,067 students. They were sampled into 100 students by using Slovin formulae. Moreover, the sample was divided through proportional cluster sampling, while their data were collected by using questionnaire and documentation. The collected data were analyzed by using descriptive analysis and multiple regression analysis. The results showed that there was a simultaneous influence ofsocioeconomic background and self-potential towards the interest in continuing study to universities showed by the significance value of $0.000<0.05$ and Adjusted R Square of $0.407(40.7 \%)$. Partially, the influence of socio-economic background contributed to the significance value of $0.025<0.05$ and $r$ square as many as $0.226(22.6 \%)$, selfpotential influenced the significance value of $0.000<0.05$ and $r$ square of 0.509 $(50.9 \%)$ towards the interest in continuing study to universities.
\end{abstract}

Keywords: Interest to study continuation; socio-economic; self-potential.

History of Article:

Received :(11 January 2017), Accepted : (21 February 2017), Publised: (15 Maret 2017)

\section{Citation (Example):}

Setiaji, Khasan \& Desy Rachmawati (2017) Minat Melanjutkan Perguruan Tinggi Siswa SMKN Kota Semarang. [Interest Continue to College Students SMKN Semarang City]. Jurnal Pendidikan Ekonomi, 10(1), 45-59.

(C) Universitas Negeri Malang 


\section{PENDAHULUAN}

Standar Pelayanan Minimal (SPM) bidang pendidikan merupakan tolok ukur kinerja pelayanan pendidikan yang diselenggarakan daerah. Berdasarkan Keputusan Menteri Pendidikan Nasional RI No.129a/U/2004 Bab IV Pasal 4 Ayat 2 tentang Standar Pelayanan Minimal Pendidikan Menengah, ada 9 SPM yang harus dipenuhi oleh Sekolah Menengah Kejuruan (SMK), salah satu SPM yang harus dipenuhi adalah $20 \%$ dari lulusan SMK melanjutkan ke perguruan tinggi yang terakreditasi.

Direktur SMK, Kementrian Pendidikan dan Kebudayaan (Kemdikbud) Mustaghfirin Amin (2017) menyimpulkan, baru 10\% lulusan SMK terserap ke perguruan tinggi. Berdasarkan data terakhir yang diperoleh dari Badan Pusat Statistik Provinsi Jawa Tengah tahun 2015 persentase lulusan siswa yang melanjutkan ke perguruan tinggi sebesar 6,22\%. Sedangkan jumlah lulusan di Kota Semarang yang melanjutkan studi ke perguruan tinggi sebanyak 17,68\%.

Data pada tabel 1. menunjukkan bahwa jumlah rata-rata lulusan SMK Negeri di Kota Semarang yang melanjutkan studi ke perguruan tinggi sebanyak 16,5\%. Hal tersebut menunjukkan bahwa lulusan SMK Negeri di Kota Semarang belum mencukupi SPM SMK yaitu 20\% dari lulusan SMK melanjutkan studi ke perguruan tinggi yang terakreditasi. Hal ini yang menjadi salah satu alasan dilakukan penelitian.

Pemerintah Kota Semarang memperhitungkan rasio kemiskinan di Kota Semarang didasarkan pada identifikasi dan verifikasi warga miskin yang dilakukan setiap 2 tahun sekali dan dituangkan kedalam Keputusan Walikota. Keputusan Walikota Semarang Nomor 050/716 tentang Penetapan Warga Miskin Kota Semarang Tahun 2013 jumlah penduduk miskin Kota Semarang hanya menyentuh angka 5,13\% atau 81.900 jiwa. Data tersebut menunjukkan bahwa jumlah penduduk di Kota Semarang didominasi oleh penduduk yang tegolong menengah keatas.

Tabel 1. Data Penelusuran Lulusan Siswa Melanjutkan Studi ke Perguruan Tinggi Sekolah Menengah Kejuruan Negeri di Kota Semarang

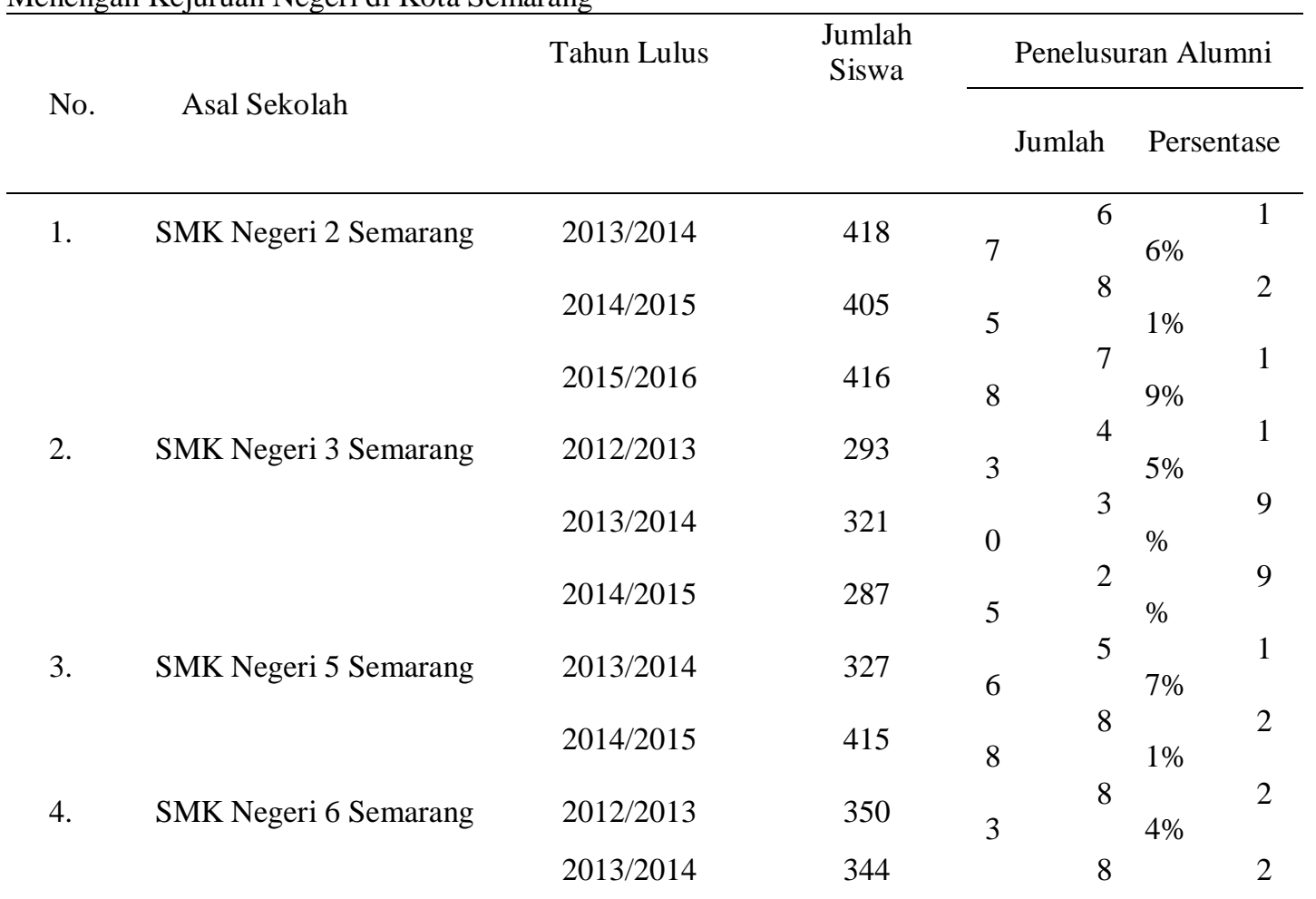




\begin{tabular}{|c|c|c|c|c|c|c|c|}
\hline \multirow{5}{*}{5.} & \multirow{5}{*}{ SMK Negeri 8 Semarang } & & \multirow[b]{2}{*}{367} & 3 & \multicolumn{3}{|c|}{$4 \%$} \\
\hline & & $2014 / 2015$ & & 2 & 6 & $7 \%$ & 1 \\
\hline & & $2013 / 2014$ & 355 & 2 & 4 & $2 \%$ & 1 \\
\hline & & $2014 / 2015$ & 352 & 3 & 5 & $5 \%$ & 1 \\
\hline & & $2015 / 2016$ & 373 & 5 & 4 & $2 \%$ & 1 \\
\hline
\end{tabular}

Sumber : Data BKK SMK

Salah satu indikator untuk mengetahui kondisi perekonomian suatu daerah dapat digambarkan dari data Produk Domestik Regional Bruto (PDRB). Ditinjau dari jumlah PDRB per kapita pada tahun 2011-2014, Kota Semarang mengalami peningkatan pada tahun 2014. Pada tahun 2013 nilainya sebesar Rp 39.124.435,42 dan tahun 2014 nilainya meningkat menjadi Rp 43.230.365,42. Peningkatan nilai PDRB per kapita ini secara umum menandakan adanya tingkat pendapatan masyarakat yang lebih baik, sejalan dengan pertumbuhan ekonomi Kota Semarang.

Pertumbuhan ekonomi di Kota Semarang setiap tahunnya mengalami peningkatan. Ada tiga kompenen pembentuk IPM Kota Semarang Tahun 2015, yang pertama Angka Harapan Hidup (AHH) merupakan kompenen yang berkontribusi terbesar terhadap Indeks Pembangunan Manusia (IPM) Kota Semarang yakni sebesar $36,46 \%$, yang berarti bahwa kesadaran masyarakat akan pentingnya kesehatan semakin meningkat, baik dari sisi kesehatan lingkungan, ketersediaan fasilitas kesehatan maupun pengetahun tentang pemeliharaan kesehatan. Selanjutnya kompenen Purchasing Power Parity (PPP) atau kompenen daya beli sebesar 32,95\% sedangkan kompenen pendidikan menyumbang 30,59\%.

Data PDRB menunjukkan bahwa kondisi perekonomian penduduk di Kota Semarang dapat dikatakan baik. Sama halnya kompenen daya beli dalam pembentukan IPM Kota Semarang memiliki persentase yang melampaui tiga per empat dari posisi ideal. Namun dalam kompenen pendidikan masih perlu dipacu, mengingat capaian kompenen ini baru pada posisi tiga per empat dari posisi ideal.

Terkait pendidikan 17,68\% dari jumlah lulusan siswa SMK di Kota Semarang yang melanjutkan studi ke perguruan tinggi. Padahal ditinjau dari segi sosial ekonomi penduduk di Kota Semarang dapat dikatakan mampu atau sanggup jika harus melanjutkan studi ke perguruan tinggi. Banyak lulusan siswa yang tidak melanjutkan studi ke perguruan tinggi tersebut dikarenakan rendahnya minat siswa untuk melanjutkan studi ke perguruan tinggi.

Minat adalah suatu keinginan atau kecenderungan hati yang tinggi terhadap sesuatu (Sutarno, 2006). Menurut Hamalik (2009) belajar dengan minat akan mendorong siswa belajar lebih baik daripada belajar tanpa minat. Minat sama halnya dengan kecerdasan dan motivasi, karena memberi pengaruh terhadap aktivitas belajar. Minat berarti kecenderungan dan kegairahan yang tinggi terhadap sesuatu (Wahyuni \& Baharuddin, 2007). Hal ini senada dengan Mulyasa (2004) yang menyatakan bahwa minat adalah kecenderungan seseorang untuk melakukan sesuatu perbuatan.

Slameto (2010) memandang bahwa minat adalah kecenderungan yang tetap untuk memperhatikan dan mengenang beberapa kegiatan dan minat selalu diikuti dengan perasaan senang dan dari situ diperoleh kepuasan. Minat belajar yang besar cenderung menghasilkan prestasi belajar yang tinggi, sebaliknya minat belajar yang kurang akan menghasilkan prestasi yang rendah (Dalyono, 2012). Menurut Holland 
(1973) minat tidak timbul sendirian, ada unsur kebutuhan, misalnya minat belajar dan lain-lain. Faktor yang mempengaruhi minat terdiri faktor dari dalam individu dan faktor dari luar individu (Djaali, 2007). Teori atribusi merupakan teori yang dikembangkan oleh Fritz Heider (1958) yang menjelaskan baha perilaku seseorang dipengaruhi oleh kombinasi kekuatan internal seperti kemampuan dan usaha. Kekuatan eksternal seperti kesulitan dalam pekerjaan atau keberuntungan (Ikhsan \& Ishak, 2005). Berdasarkan penelitian yang dilakukan oleh Edward L. Deci, Robert J. Vallerand, Luc G. Pelletier, dan Richard M. Ryan pada tahun 2011 menunjukkan bahwa minat siswa dalam belajar dapat menghasilkan kualitas belajar yang tinggi dan pemahaman konseptual yang baik serta dapat menumbuhkan kedewasaan dan penyesuaian.

Safran (1988) mengklasifikasikan minat menjadi empat jenis yaitu minat yang di ekspresikan, minat yang diwujudkan, dan minat yang diinventariskan (Sukardi, 1993). Minat dapat berkembang apabila seseorang memiliki perhatian yang khusus terhadap hal yang diminatinya. Perhatian merupakan pemusatan konsentrasi dari seluruh aktivitas individu yang ditujukan kepada sesuatu atau sekumpulan objek (Prawira, 2016). Hal ini senada dengan Salam (2004) yang menyatakan bahwa minat adalah perhatian yang bersifat khusus. Kecenderungan itu tetap bertahan sekalipun seseorang sibuk mengerjakan hal lain. Kegiatan yang diikuti seseorang karena kegiatan itu menarik baginya, merupakan perwujudan minatnya. Ketertarikan menyebabkan siswa memberikan perhatian lebih terhadap perguruan tinggi dan jurusan yang akan mereka masuki.

Syah (2008) mendefinisikan bahwa minat melanjutkan pendidikan ke perguruan tinggi adalah ketertarikan siswa untuk melanjutkan pendidikan perguruan tinggi yang tumbuh secara sadar dalam diri siswa tersebut. Minat mengarahkan perhatian seseorang kepada suatu tujuan dan merupakan dorongan bagi perhatian itu. Apa yang menarik minat seseorang mendorongnya untuk berbuat lebih giat dan lebih baik (Purwanto, 2010). Faktor yang mempengaruhi minat adalah: (1) motivasi dan cita-cita; (2) sikap terhadap suatu objek; (3) keluarga; (4) fasilitas; (5) teman pergaulan (Ahmadi, 2007). Minat melanjutkan studi ke perguruan tinggi memiliki unsur perasaan senang, keinginan, perhatian, ketertarikan, kebutuhan, harapan, dorongan, dan kemauan untuk melanjutkan pendidikan ke jenjang yang lebih tinggi setelah lulus sekolah menengah, yaitu perguruan tinggi. Hasil empiris berdasarkan penelitian pendidikan menunjukkan bahwa kelas sosial, karakteristik individu seperti kecerdasan mempengaruhi minat seseorang dalam proses dan hasil belajar (Krapp, 2007).

Kehidupan perekonomian keluarga juga bisa menjadi satu faktor yang mempengaruhi minat siswa untuk melanjutkan pendidikan ke jenjang yang lebih tinggi. Sosial ekonomi adalah gambaran tentang keadaan seseorang atau suatu masyarakat yang ditinjau dari segi sosial ekonomi seperti jabatan, agama, jenis, dan luas rumah, keturunan, partisipasi dalam kegiatan organisasi, keadaan tempat tinggal, tingkat pendidikan, tingkat penghasilan, dan jenis pekerjaan (Nasution, 2010). Dalam penelitian ini, pengertian sosial ekonomi berdasarkan definisi diatas latar belakanng ekonomi keluarga atau orang tua yang diukur dengan tingkat pendidikan, jenis pekerjaan, dan tingkat pendapatan orang tua (Simamora, 2004).

Menurut Hartomo \& Aziz (2008) menyatakan bahwa status sosial merupakan kedudukan dalam suatu kelompok yang dilihat melalui dua aspek: (1) aspek statis adalah kedudukan atau derajat yang dibedakan dalam suatu kelompok yang dapat 
dibedakan dengan individu lainnya; (2) aspek dinamis adalah peranan sosial tertentu yang berhubungan dengan pengertian jabatan, fungsi, dan tingkah laku formal serta jasa yang diharapkan dari fungsi dan jabatan tersebut. Abdulsyani (2002) berpendapat bahwa indikator yang dapat menentukan sosial ekonomi adalah: (1) memiliki kekayaan yang bernilai ekonomis; (2) status dasar fungsi dalam pekerjaan; (3) kesalehan dalam beragama; (4) status dasar keturunan; (5) latar belakang rasial dan lamanya seseorang tinggal disuatu tempat; (6) status dasar jenis kelamin dan umur. Nitisusastro (2013) mengungkapkan bahwa faktor pembeda yang paling menonjol dalam kelompok masyarakat adalah: (1) tingkat pendidikan; (2) jenis pekerjaan; (3) tingkat penghasilan.

Kaitannya dengan minat melanjutkan studi, orang tua sangat berperan aktif untuk mendorong ketercapaiannya cita-cita anaknya. Orang tua yang memiliki latar belakang pendidikan yang bagus dan memiliki materi yang mumpuni, akan selalu memberikan motivasi untuk anaknya guna melanjutkan studi ke jenjang yang lebih tinggi dan senantiasa membiayai anaknya untuk mendapatkan pendidikan yang baik.

Sosial ekonomi oang tua meliputi tingkat pendidikan orang tua dan kondisi lingkungan tempat tinggal juga mempengaruhi minat siswa untuk menempuh pendidikan setinggi mungkin. Sebagian besar orang tua menginginkan pendidikan anaknya lebih tinggi dari mereka. Orang tua menginginkan kualitas kehidupan anaknya dimasa yang akan datang jauh lebih baik dari yang sudah mereka dapatkan.

Keinginan ini yang mendorong orang mereka untuk menyekolahkan anak setinggi mungkin. Kondisi ekonomi meliputi tingkat pendapatan, tingkat pengeluaran, dan pemenuhan kebutuhan hidup serta kepemilikan harta yang bernilai ekonomi akan mempengaruhi minat siswa untuk melanjutkan studi ke perguruan tinggi. Semakin tinggi tingkat pendapatan orang tua maka siswa akan semakin termotivasi untuk melanjutkan pendidikannya, karena tingkat pendapatan orang tua akan berperan dalam mendukung pembiayaan pendidikan, penyediaan sarana dan prasarana bagi kelancaran pendidikan anaknya. Bagi orang tua yang mempunyai kondisi sosial dan kondisi ekonomi yang kuat atau tinggi tentu tidak akan merasa berat untuk membiayai pendidikan anak-anaknya sampai dengan jenjang tertinggi (Sumardi \& Evers, 1982). Zhang dan Postiglione (2000) dalam penelitiannya menunjukkan bahwa status sosial ekonomi berpengaruh terhadap gaya berfikir seseorang. Siswa cenderung mendapatkan nilai prestasi akademik yang lebih baik apabila sesuai dengan gaya berfikir sesuai dengan pemikiran mereka. Indikator sosial ekonomi dalam penelitian ini adalah tingkat pendidikan ayah, pendapatan dan lingkungan.

Biaya pendidikan yang tinggi kadang menjadi kendala bagi mereka yang berasal dari keluarga yang kurang mampu. Banyak dari mereka terpaksa putus sekolah atau tidak dapat melanjutkan studi ke jenjang pendidikan yang lebih tinggi karena keterbatasan biaya. Tidak sedikit siswa memilih meninggalkan pendidikannya demi membantu perekonomian keluarga.

Hasil penelitian Arsyad (2015) menyebutkan bahwa terdapat pengaruh positif dan signifikan antara sosial ekonomi orang tua terhadap minat melanjutkan ke perguruan tinggi. Sama halnya penelitian yang dilakukan oleh Andanawari bahwa terdapat pengaruh positif dan signifikan antara pendidikan orang tua (sosial ekonomi) terhadap minat melanjutkan studi ke perguruan tinggi. Namun ada penelitian Sari (2015) menyebutkan bahwa tidak ada pengaruh secara signifikan pendapatan orang tua (sosial ekonomi) terhadap minat melanjutkan studi ke perguruan tinggi. Oleh karena itu, perlu dilakukan penelitian lanjutan untuk menjelaskan hubungan kausal antara sosial ekonomi dengan minat melanjutkan studi ke perguruan tinggi. 
Potensi dapat diartikan sebagai kemampuan dasar yang masih terpendam yang menunggu untuk diwujudkan menjadi kekuatan yang nyata dalam diri seseorang. Proses pendidikan seperti yang telah kita ketahui adalah upaya sadar dan terencana untuk mewujudkan suasana belajar agar peserta didik secara aktif mengembangkan potensi dirinya untuk memiliki kekuatan spiritual keagamaan, pengendalian diri, kepribadian, kecerdasan, akhlak mulia, serta ketrampilan yang diperlukan dirinya, masyarakat, bangsa dan negara (Sisdiknas, Bab 1, Pasal 1, ayat 1).

Potensi itu tidak akan muncul begitu saja tanpa siswa kenali dan kembangkan. Potensi diri siswa adalah yang berkaitan dalam proses dan hasil belajar siswa baik aspek kognitif, afektif, maupun psikomotorik. Aspek tersebut dapat diketahui melalui rerata nilai rapor seluruh mata pelajaran siswa. Karena dalam memberikan nilai, guru tidak hanya melihat aspek kognitif saja (nilai tugas, ulangan, ujian, dan sebagainya) namun juga melihat pada saat proses pembelajaran di kelas sehingga nilai tersebut juga menyangkut aspek afektif dan aspek psikomotorik siswa.

Potensi diri yang dimiliki oleh seseorang berpengaruh besar pada pembentukan terhadap pemahaman diri sendiri, hal ini berkaitan erat dengan prestasi yang hendak diraih didalam hidupnya. Lulusan sekolah menengah yang akan melanjutkan pendidikan ke jenjang yang lebih tinggi yaitu perguruan tinggi mereka akan lebih memahami kekurangan dan kelebihan yang dimiliki dan jika terolah dengan baik maka akan dapat memperkembangkan diri orang tersebut baik secara fisik maupun mental.

Secara sederhana potensi adalah sesuatu yang bisa kita kembangkan (Majdi, 2007). Potensi diartikan sebagai kemampuan dasar dari sesuatu yang masih terpendam didalamnya yang menunggu untuk diwujudkan menjadi sesuatu kekuatan nyata dalam diri sesuatu tersebut (Wiyono, 2006). Potensi bisa disebut sebagai kekuatan, energi, atau kemampuan yang terpendam yang dimiliki dan belum dimanfaatkan secara optimal. Potensi diri yang dimaksud adalah kekuatan yang masih terpendam yang berupa fisik, karakter, minat, bakat, kecerdasan, dan nilai-nilai yang terkandung dalam diri tetapi belum dimanfaatkan dan diolah secara optimal (Prihadhi, 2004).

Habsari (2005) menambahkan bahwa potensi adalah kemampuan dan kekuatan yang dimiliki oleh seseorang baik fisik maupun mental dan mempunyai kemungkinan untuk dikembangkan bila dilatih dan ditunjang dengan sarana yang baik. Manusia memiliki banyak potensi baik yang disadari atau tidak diantaranya: (1) potensi berfikir, manusia memiliki potensi untuk belajar informasi-informasi baru, menghubungkan berbagai informasi, serta menghasilkan pemikiran baru; (2) potensi emosi, setiap manusia memiliki potensi cita-rasa, yang dengannya manusia dapat memahami perasaan orang lain, memperhatikan dan diperhatikan, menghargai dan dihargai; (3) manusia memiliki potensi yang luar biasa untuk membuat gerakan fisik yang efektif dan efisien serta memiliki kekuatan fisik yang tangguh. Orang yang berbakat dalam bidang fisik mampu mempelajari olahraga dengan cepat dan selalu menunjukkan permainan yang baik. Gerakan fisik yang mereka tunjukkan dilandasi oleh kecerdasan intelektual mereka, khususnya intelektualitas yang berkaitan denga fisik; (4) potensi sosial, pemilik potensi sosial yang besar memiliki kapasitas menyesuaikan diri dan mempengaruhi orang lain. Kemampuan menyesuaikan diri dan mempengaruhi orang lain didasari kemampuan belajar, baik dalam dataran pengetahuan maupun keterampilan (Nashori, 2003). 
Menurut Wibowo (2007) minimal ada empat kategori potensi yang terdapat dalam diri manusia sejak lahir yaitu, potensi otak, emosi, fisik, dan spiritual. Semua potensi ini dapat dikembangkan pada tingkat yang tidak terbatas. Ahli lain berpendapat bahwa manusia itu diciptakan dengan potensi diri terbaik dibandingkan dengan makhluk Tuhan yang lain, ada empat macam potensi yang dimiliki manusia yaitu, potensi intelektual, emosional, spiritual dan fisik. Senada dengan Wibowo, Sujana (2014) memandang potensi kecerdasan yang dimiliki seseorang dapat digunakan untuk mempelajari dan memahami sesuatu. Potensi kecerdasan tersebut adalah: (1) kecerdasan intelektual adalah kecerdasan yang menitikberatkan pada kemampuan intelek manusia pada kemampuan aritmetis, logis dan verbal (Nggermanto, 2002); (2) kecerdasan emosional, menurut Goleman (2000) adalah kemampuan untuk mengenali perasaan kita sendiri, kemampuan memotivasi diri sendiri, kemampuan mengelola emosi dengan baik pada diri sendiri dan dalam hubungan dengan orang lain (Nggermanto, 2002); (3) kecerdasan spiritual, menurut Danah Zohar (2001) kecerdasan spriritual adalah kecerdasan yang bertumpu pada bagian dalam diri kita yang berhubungan dengan kearifan luar ego, atau jiwa sadar (Nggermanto, 2002).

Studi yang dilakukan oleh Indriyanti (2013) menunjukkan bahwa faktor yang paling besar mempengaruhi minat melanjutkan studi ke perguruan tinggi adalah potensi diri. Demikian juga penelitian yang dilakukan oleh Sumakta (2015) menunjukkan bahwa faktor yang paling besar mempengaruhi minat melanjutkan studi ke perguruan tinggi yaitu prestasi belajar (potensi diri).

Penelitian ini bertujuan untuk mengetahui:

1. Pengaruh sosial ekonomi terhadap minat melanjutkan studi ke perguruan tinggi pada siswa kelas XI SMK Negeri se-Kota Semarang.

2. Pengaruh potensi diri terhadap minat melanjutkan studi ke perguruan tinggi pada siswa kelas XI SMK Negeri se-Kota Semarang.

3. Pengaruh sosial ekonomi dan potensi diri terhadap minat melanjutkan studi ke perguruan tinggi pada siswa kelas XI SMK Negeri se-Kota Semarang.

\section{METODE}

Jenis penelitian yang digunakan dalam penelitian ini adalah penelitian kausal asosiatif dengan menggunakan pendekatan kuantitatif (Prasetyo, 2008). Pengumpulan data menggunakan metode dokumentasi dan metode kuesioner. Data yang diperoleh akan diwujudkan dalam bentuk angka dan dianalisis statistik untuk menunjukkan pengaruh sosial ekonomi dan potensi diri terhadap minat melanjutkan studi ke perguruan tinggi pada siswa kelas XI SMK Negeri se-Kota Semarang.

Populasi dalam penelitian ini adalah seluruh siswa kelas XI SMK Negeri seKota Semarang tahun ajaran 2017/2018 yang diambil berdasarkan karakteristik bidang keahlian yang berjumlah 5.067 siswa. Sampel dalam populasi tersebut bersifat representatif. Pengambilan sampel menggunakan rumus Slovin dengan taraf kesalahan pengambilan sampel yang ditolerir yaitu $10 \%$. Berdasarkan rumus tersebut diketahui sampel sebanyak 100 siswa.

Teknik pengambilan sampel dalam penelitian ini adalah teknik proportional cluster sampling, teknik pengambilan sampel dengan melihat proporsi tiap bidang keahlian berdasarkan cluster Bisnis dan Manajemen, cluster Kesehatan, cluster Pariwisata, cluster Perikanan dan Kelautan, cluster Teknologi dan Rekayasa, cluster Teknologi Informasi dan Komunikasi yang telah ditetapkan sehingga masing-masing kelas dalam populasi tersebut dapat terwakili (Suharyadi, 2013). 
Metode analisis data yang digunakan dalam penelitian ini adalah metode analisis deskriptif dan metode analisis regresi berganda (Sudjana, 2005). Statistik deskriptif digunakan untuk menganalisis data dengan cara mendeskripsikan atau menggambarkan data yang telah terkumpul (Ghozali, 2011). Analisis regresi berganda bertujuan untuk mencari nilai ketergantungan dari variabel terikat yakni minat melanjutkan studi ke perguran tinggi dengan dua variabel bebas yaitu kondisi sosial ekonomi dan potensi diri.

\section{HASIL DAN PEMBAHASAN}

Perhitungan analisis distribusi frekuensi untuk variabel minat melanjutkan studi pada tabel 2.

Tabel 2. Distribusi frekuensi variabel minat melanjutkan studi

\begin{tabular}{|l|l|l|l|l|}
\hline No. & Interval & Kriteria & F & Persentase \\
\hline 1 & $63-74$ & SangatTinggi & 47 & $47 \%$ \\
\hline 2 & $51-62$ & Tinggi & 48 & $48 \%$ \\
\hline 3 & $39-50$ & Cukup & 4 & $4 \%$ \\
\hline 4 & $27-38$ & Rendah & 1 & $1 \%$ \\
\hline 5 & $15-26$ & SangatRendah & 0 & $0 \%$ \\
\hline Jumlah & & $\mathbf{1 0 0}$ & $\mathbf{1 0 0} \%$ \\
\hline Rata-rata & & $\mathbf{6 1 , 4 2}$ \\
\hline Kategori & \multicolumn{2}{|c|}{ Tinggi } \\
\hline
\end{tabular}

Sumber: Data primer yang diolah, 2017

Berdasaran kategori dekriptif menunjukkan bahwa tingkat variabel minat melanjutkan studi ke perguruan tinggi termasuk dalam kategori tinggi. Hal ini menunjukkan bahwa siswa SMK Negeri se-Kota Semarang memiliki perasaan tertarik, senang dan berkeinginan untuk melanjutkan studi ke perguruan tinggi.

Perhitungan analisis distribusi frekuensi untuk variabel sosial ekonomi pada tabel 3.

Tabel 3. Distribusi frekuensi variabel sosial ekonomi

\begin{tabular}{|c|c|c|c|c|}
\hline No. & Interval & Kriteria & F & Persentase \\
\hline 1 & $52-61$ & SangatTinggi & 23 & $23 \%$ \\
\hline 2 & $42-51$ & Tinggi & 59 & $59 \%$ \\
\hline 3 & $32-41$ & Cukup & 17 & $17 \%$ \\
\hline 4 & $22-31$ & Rendah & 1 & $1 \%$ \\
\hline 5 & $12-21$ & SangatRendah & 0 & $0 \%$ \\
\hline \multicolumn{2}{|l|}{} \\
\hline
\end{tabular}

Sumber: Data primer yang diolah, 2017

Berdasarkan kategori deskriptif menunjukkan bahwa kondisi sosial ekonomi orang tua siswa SMK Negeri se-Kota Semarang termasuk dalam kategori tinggi. Hal ini dapat diartikan bahwa kondisi sosial ekonomi orang tua siswa yang dilihat berdasarkan tingkat pendidikan orang tua, jenis pekerjaan orang tua dan tingkat pendapatan orang tua sudah dikatakan baik dalam memenuhi kebutuhan dan fasilitas belajar anak dan mendukung peningkatan minat anak untuk melanjutkan studi ke perguruan tinggi. 
Tabel 4. Distribusi frekuensi variabel potensi diri

\begin{tabular}{|c|c|c|c|c|}
\hline No. & Interval & Kriteria & F & Persentase \\
\hline 1 & $99-117$ & SangatTinggi & 46 & $46 \%$ \\
\hline 2 & $80-98$ & Tinggi & 53 & $53 \%$ \\
\hline 3 & $61-79$ & Cukup & 1 & $1 \%$ \\
\hline 4 & $42-60$ & Rendah & 0 & $0 \%$ \\
\hline 5 & $23-41$ & SangatRendah & 0 & $0 \%$ \\
\hline \multicolumn{2}{r|}{ Jumlah } & $\mathbf{1 0 0}$ & $\mathbf{1 0 0 \%}$ \\
\hline & Rata-rata & \multicolumn{2}{|c|}{ Tinggi } \\
\hline
\end{tabular}

Sumber: Data primer yang diolah, 2017

Berdasarkan tabel 4. kategori deskriptif potensi diri menunjukkan bahwa ratarata siswa SMK Negeri se-Kota Semarang memiliki potensi diridiantaranya yaitu, potensi intelektual, potensi emosional, potensi spiritual dan potensi fisik termasuk dalam kategori tinggi.

Tabel 5. Analisis regresi berganda

Coefficients $^{\mathrm{a}}$

\begin{tabular}{|c|c|c|c|c|c|c|}
\hline \multirow[t]{2}{*}{ Model } & & \multicolumn{2}{|c|}{$\begin{array}{l}\text { Unstandardized } \\
\text { Coefficients }\end{array}$} & \multirow{2}{*}{\begin{tabular}{|l|}
$\begin{array}{r}\text { Standardize } \\
\text { d Coefficients }\end{array}$ \\
Beta \\
\end{tabular}} & \multirow[t]{2}{*}{$\mathrm{T}$} & \multirow[t]{2}{*}{ Sig. } \\
\hline & & B & Std. Error & & & \\
\hline \multirow{4}{*}{1} & (Constant) & 9.249 & 6.317 & \multirow{4}{*}{$\begin{array}{l}.204 \\
.521\end{array}$} & 1.464 & .146 \\
\hline & Sosial Ekonomi & .217 & .095 & & 2.280 & .025 \\
\hline & & .429 & .074 & & 5.831 & .000 \\
\hline & PotensiDiri & & & & & \\
\hline
\end{tabular}

a. Dependent Variable: Minat

Sumber: Data primer yang diolah, 2017

Berdasarkan tabel 5. diperoleh persamaan regresi:

$Y=9,249+0,217 X_{1}+0,429 X_{2}+e$

Persamaan regresi tersebut dapat diartikan (1) konstanta sebesar 9,249 artinya bahwa ketika sosial ekonomi dan potensi diri bernilai 0 (nol), maka tingkat minat melanjutkan studi ke perguruan tinggi adalah sangat rendah; (2) koefisien regresi variabel sosial ekonomi sebesar 0,217 artinya bahwa jika sosial ekonomi mengalami kenaikan 1 nilai sedangkan variabel potensi diri nilainya tetap, maka variabel minat melanjutkan studi ke perguruan tinggi akan mengalami peningkatan sebesar 0,217. Koefisien bernilai positif sehingga terjadi hubungan positif antara variabel sosial ekonomi dengan minat emlanjutkan studi ke perguruan tinggi. Semakin baik sosial ekonomi orang tua maka semakin tinggi pula minat siswa melanjutkan studi ke perguruan tinggi; (3) koefisien regresi variabel potensi diri sebesar 0,429 artinya bahwa jika potensi diri mengalami kenaikan sebesar 1 nilai, sedangkan variabel sosial ekonomi bernilai tetap maka variabel minat melanjutkan studi ke perguruan tinggi akan mengalami peningkatan sebesar 0,429. Koefisien bernilai positif sehingga terjadi hubungan positif antara variabel potensi diri dengan minat melanjutkan studi ke 
perguruan tinggi. Semakin tinggi tingkat potensi diri siswa maka semakin tinggi pula minat siswa melanjutkan studi ke perguruan tinggi.

Pengujian hipotesis secara simultan pada tabel 6. menunjukkan bahwa nilai signifikansi kurang dari 0,05 sehingga hipotesis ketiga diterima. Artinya, ada pengaruh antara sosial ekonomi dan potensi diri terhadap minat siswa melanjutkan studi ke perguruan tinggi pada siswa kelas XI SMK Negeri se-Kota Semarang tahun ajaran $2017 / 2018$.

Tabel 6. Hasil uji F

ANOVA $^{\mathrm{a}}$

\begin{tabular}{|c|c|c|c|c|c|}
\hline Model & Sum of Squares & df & Mean Square & F & Sig. \\
\hline Regression & 1783.519 & 2 & 891.759 & 35.037 & $.000^{\mathrm{b}}$ \\
Residual & 2468.841 & 97 & 25.452 & & \\
Total & 4252.360 & 99 & & & \\
\hline
\end{tabular}

a. Dependent Variable: Minat

b. Predictors: (Constant), PotensiDiri, SosialEkonomi

Sumber: Data primer yang diolah, 2017

Hasil adjusted pada tabel 7. Menunjukkan bahwa secara simultan variabel

sosial ekonomi dan potensi diri berpengaruh terhadap minat melanjutkan studi ke perguruan tinggi pada siswa kelas XI SMK Negeri se-Kota Semarang tahun ajaran 2017/2018 sebesar 40,7\%.

Tabel 7. Hasil uji koefisien determinasi ( )

Model Summary ${ }^{\mathrm{b}}$

\begin{tabular}{|c|c|c|c|c|}
\hline Model & $\mathrm{R}$ & $\mathrm{R}$ Square & Adjusted R Square & $\begin{array}{c}\text { Std. Error of the } \\
\text { Estimate }\end{array}$ \\
\hline 1 & $.648^{\mathrm{a}}$ & .419 & .407 & 5.045 \\
\hline
\end{tabular}

a. Predictors: (Constant), PotensiDiri, SosialEkonomi

b. Dependent Variable: Minat

Sumber: Data primer yang diolah, 2017

Berdasarkan hasil analisis deskriptif variabel minat melanjutkan studi ke perguruan tinggi masuk dalam kategori tinggi. Hal ini dibuktikan dengan rata-rata variabel minat melanjutkan studi ke perguruan tinggi sebesar 61,42. Variabel sosial ekonomi orang tua dikatakan tinggi karena memiliki nilai rata-rata 46,69 dan variabel potensi diri memiliki nilai rta-rata sebesar 98,05. Analisis deskriptif tersebut mendukung diterimanya hipotesis ketiga.

Hasil penelitian ini mendukung teori yang dikemukakan oleh Djaali (2007) minat melanjutkan studi ke perguruan tinggi dipengaruhi oleh faktor yang berasal dari dalam diri dan faktor dari luar. Faktor dari dalam diri misalnya intelegensi yaitu kecerdasan yang dimiliki seseorang yang besar sekali pengaruhnya terhadap kemajuan belajar dan tumbuh kembangnya minat seseorang. Faktor dari luar misalnya keluarga, yaitu situasi dan kondisi sosial ekonomi orang tua yang berpengaruh terhadap keberhasilan anak. Hasil penelitian ini juga mendukung teori yang dikemukakan oleh Syah (2008) mengungkapkan bahwa minat mampu mempengaruhi keputusan siswa 
melanjutkan pendidikan ke perguruan tinggi dipengaruhi oleh dua faktor, yaitu: (1) faktor internal (faktor dari dalam diri siswa) yakni keadaan atau kondisi jasmani dan rohani siswa. Faktor ini meliputi dua aspek seperti aspek fisiologi (yang bersifat jasmani) seperti mata dan telinga. Aspek psikologis (yang bersifat rohani) seperti intelegensi, sikap, bakat, dan motivasi; (2) faktor eksternal (faktor dari luar diri siswa) yaitu kondisi lingkungan sosial seperti keluarga, guru, staf, masyarakat, dan teman. Lingkungan non sosial seperti rumah, sekolah, peralatan, dan alam.

Hasil penelitian ini sejalan dengan penelitian yang dilakukan oleh Susan J. Lea, David Stephenson, dan Juliette Troy pada tahun 2003 menunjukkan bahwa minat belajar memiliki pengaruh yang signifikan dalam belajar di perguruan tinggi. Hal ini senada dengan penelitian yang dilakukan oleh I. C. Mc Manus dan A. Furngam pada tahun 2006 hasil penelitian menunjukkan bahwa intelegensi mempunyai pengaruh yang yang signifikan terhadap minat belajar seni. Latar belakang social seseorang seperti pekerjaan orang tua dan kelas social memiliki pengaruh dalam minat belajar seni.

Menurut Syaukani (2002: p. 132) orang tua memiliki nilai yang signifikan dalam hubungannya dengan proses pendidikan anak. Orang tua harus berperan serta dalam memilih pendidikan dan memperoleh informasi tentang perkembangan pendidikan anaknya. Pendidikan anak tidak hanya selesai dibangku sekolah menengah saja. Orang tua harus turut serta berpartisipasi dalam mendorong anak melanjutkan sekolah ke jenjang perguruan tinggi. Banyak anak ingin memperoleh pendidikan yang lebih tinggi akan tetapi dihalangi oleh ketiadaan biaya.

Hasil uji statistik t pada tabel 5 menunjukkan bahwa nilai signifikansi variabel sosial ekonomi kurang dari 0,05 sehingga hipotesis pertama diterima. Hal ini menunjukkan bahwa sosial ekonomi orang tua berpengaruh terhadap minat melanjutkan studi ke perguruan tinggi pada siswa kelas XI SMK Negeri se-Kota Semarang tahun ajaran 2017/2018 secara parsial.

Hasil perhitungan secara parsialpada tabel 8. menunjukkan bahwa variabel sosial ekonomi berpengaruh terhadap minat melanjutkan studi ke perguruan tinggi pada siswa kelas XI SMK Negeri se-Kota Semarang tahun ajaran 2017/2018 sebesar $22,6 \%$. Hasil analisis deskriptif variabel sosial ekonomi menunjukkan bahwa secara keseluruhan rata-rata siswa beranggapan bahwa sosial ekonomi orang tua mereka dalam kategori tinggi. Hal ini dibuktikan dengan rata-rata variabel sosial ekonomi orang tua sebesar 46,69.

Penelitian ini selaras dengan teori yang dikemukakan oleh Nasution (2010) bahwa kehidupan perekonomian keluarga juga bisa menjadi satu faktor yang mempengaruhi minat siswa untuk melanjutkan pendidikannya ke jenjang yang lebih tinggi. Sosial ekonomi bisa menjadi faktor yang kuat dalam prestasi akademik dan menentukan kualitas pendidikan dan peluang terhadap pendidikan yang lebih tinggi (Papalia, Old, \& Feldman, 2008).

Hasil penelitian ini sejalan dengan penelitian yang dilakukan oleh Arsyad (2015) bahwa terdapat pengaruh yang signifikan antara status sosial ekonomi keluarga terhadap minat siswa melanjutkan ke perguruan tinggi. Sama halnya penelitian yang dilakukan oleh Nasution (2011) bahwa status sosial ekonomi orang tua mempengaruhi minat siswa anak dalam melanjutkan pendidikan ke perguruan tinggi.

Penelitian yang dilakukan oleh Paula Wilcox, Sandra Winn dan Marylynn Fyvie-Gauld (2005) menunjukkan bahwa dukungan social dari keluarga baik dalam aspek material memberikan kepercayaan diri siswa dalam hal akademis. Hasil 
penelitian yang dilakukan oleh Aden Ginanjar Andanawari (2010) menunjukkan bahwa faktor-faktor yang berpengaruh terhadap minat siswa melanjutkan keperguruan tinggi antara jenis kelamin, rata-rata penghasilan orangtua serta faktor pendorong.

Berdasarkan hasil uji statistik $\mathrm{t}$ pada tabel 5 menunjukkan bahwa nilai signifikansi variabel potensi diri kurang dari 0,05 sehingga hipotesis kedua diterima. Hal ini menunjukkan bahwa potensi diri berpengaruh terhadap minat melanjutkan studi ke perguruan tinggi pada siswa kelas XI SMK Negeri se-Kota Semarang tahun ajaran 2017/2018 secara parsial.

Tabel 8. Hasil uji koefisien determinasi

Coefficients $^{\mathrm{a}}$

\begin{tabular}{|c|c|c|c|c|c|c|c|c|}
\hline \multirow{2}{*}{ Model } & \multicolumn{2}{|c|}{$\begin{array}{c}\text { Unstandardized } \\
\text { Coefficients }\end{array}$} & \multirow{2}{*}{$\begin{array}{c}\begin{array}{c}\text { Standardiz } \\
\text { ed } \\
\text { Coefficient } \\
\text { s }\end{array} \\
\text { Beta }\end{array}$} & \multirow{2}{*}{$\mathrm{t}$} & \multirow{2}{*}{ Sig. } & \multicolumn{3}{|c|}{ Correlations } \\
\hline & B & $\begin{array}{l}\text { td. } \\
\text { Error }\end{array}$ & & & & Zero-order & Partial & Part \\
\hline (Constant) & 9.249 & 317 & & 1.464 & .146 & & & \\
\hline $\begin{array}{c}\text { SosialEkono } \\
\mathrm{mi}\end{array}$ & .217 & 095 & .204 & 2.280 & .025 & .465 & .226 & .176 \\
\hline PotensiDiri & .429 & 074 & .521 & 5.831 & .000 & .623 & .509 & .451 \\
\hline
\end{tabular}

a. Dependent Variable: Minat

Sumber: Data primer yang diolah, 2017

Hasil perhitungan secara parsial pada tabel 8. menunjukkan bahwa variabel potensi diri berpengaruh terhadap minat melanjutkan studi ke perguruan tinggi pada siswa kelas XI SMK Negeri se-Kota Semarang tahun ajaran 2017/2018 sebesar 50,9\%. Hasil analisis deskriptif variabel potensi diri menunjukkan bahwa secara keseluruhan rata-rata siswa beranggapan bahwa potensi diri yang mereka miliki termasuk dalam kategori tinggi. Hal ini dibuktikan dengan rata-rata variabel potensi diri sebesar 98,05.

Penelitian ini selaras dengan teori yang dikemukakan oleh La Rose (1993) bahwa potensi diri yang dimiliki oleh seseorang berpengaruh besar pada pembentukan pemahaman diri sendiri, hal ini berkaitan erat dengan prestasi yang hendak diraih didalam hidupnya. Lulusan sekolah menengah yang akan melanjutkan pendidikan ke jenjang yang lebih tinggi yaitu perguruan tinggi mereka akan lebih memahami kekurangan dan kelebihan yang dimiliki dan jika terolah dengan baik maka akan dapat memperkembangkan diri orang tersebut secara fisik maupun mental. Orang yang memahami potensi dirinya bisa dilihat dalam sikap dan perilakunya sehari-hari, kehidupan keluarga, sekolah dan masyarakat (Sugiharso, 2009).

Hasil penelitian ini sejalan dengan penelitian yang dilakukan oleh Indriyanti (2013) bahwa faktor yang paling besar mempengaruhi minat siswa melanjutkan studi ke perguruan tinggi adalah potensi diri. Penelitian yang dilakukan oleh Chen (2013) menyebutkan bahwa faktor kognitif (kecerdasan/potensi diri) seseorang merupakan faktor yang berpengaruh terhadap minat situasional. 


\section{KESIMPULAN}

Berdasarkan hasil penelitian dan pembahasan, maka peneliti dapat menarik kesimpulan yaitu ada pengaruh sosial ekonomi dan potensi diri terhadap minat melanjutkan studi ke perguruan tinggi pada siswa kelas XI SMK Negeri se-Kota Semarang tahun ajaran 2017/2018 secara simultan sebesar 40,7\%. Ada pengaruh sosial ekonomi terhadap minat melanjutkan studi ke perguruan tinggi pada siswa kelas XI SMK Negeri se-Kota Semarang tahun ajaran 2017/2018 secara parsial sebesar 22,6\%. Faktor yang paling besar mempengaruhi minat melanjutkan studi ke perguruan tinggi pada siswa kelas XI SMK Negeri se-Kota Semarang tahun ajaran 2017/2018 adalah potensi diri dengan pengaruh secara parsial sebesar 50,9\%.

\section{DAFTAR PUSTAKA}

Abdulsyani. (2002) Sosiologi, Skematika, Teori, dan Terapan. Jakarta: Bumi Aksara. Ahmadi, A. (2007) Psikologi Sosial. Jakarta: Rineka Cipta.

Amin, Mustaghfirin (2017) Lulusan Sekolah Menengah Kejuruan (SMK). tersedia: (http://www.jawapos.com/read/2017/01/23/104281/baru-10-persen-lulusan-smkmelanjutkan-kuliah), (diakses pada 09 Maret 2017).

Andanawari, A. G. (2010) Faktor-Faktor yang Mempengaruhi Minat Siswa Melanjutkan Pendidikan ke Perguruan Tinggi dengan Menggunakan Regresi Logistik (Studi Kasus : Minat Siswa SMU/sederajat di Kabupaten Garut terhadap Perguruan Tinggi. Tesis. Bogor: Institut Pertanian Bogor.

Arsyad, M (2015) Pengaruh Status Sosial Ekonomi Keluarga terhadap Minat Melanjutkan ke Perguruan Tinggi. Dalam Jurnal Mahasiswa BK An-Nur. Hal 18 Banjarmasin : FKIP Universitas Islam Kalimantan.

Berita Resmi Statistik Badan Pusat Statistik Kota Semarang No. 33740.1642 Tentang Indeks Pembangunan Manusia (IPM) Kota Semarang Tahun 2015.

Chen, Ang, \& Darst, Paul W. 2013.Situational Interest in Physical Education: A Function of Learning Task Design. Journal of Commerce Study. London: Department of Exercise Science and Physical Education, Arizona State University.

Data Pokok Sekolah Menengah Kejuruan.tersedia: http://datapokok.ditpsmk.net (diaksespada 10 April 2017).

Dalyono (2012) Psikologi Pendidikan. Jakarta: Rineka Cipta.

Djaali (2007) Psikologi Pendidikan. Jakarta: Bumi Aksara.

Deci, Edward L, dkk (2011) Motivation and Education: The Self-Determination Perspective. Journal of Educational Psychologist. London: Department of Psychology, University of Rochester.

Ghozali, I. (2011) Aplikasi Analisis Multivariate dengan Program IBM SPSS 19. Semarang: Badan Penerbit Universitas Diponegoro.

Habsari, Sri (2005) Bimbingan Dan Konseling SMA Kelas XI. Jakarta. Grasindo

Hamalik, O (2009) Proses Belajar Mengajar. Jakarta: Bumi Aksara.

Hartomo, \& Aziz, A (2008) Ilmu Sosial Dasar. Jakarta: Bumi Aksara.

Ikhsan, A., \& Ishak, M (2005) Akuntasi Keperilakuan. Jakarta: Salemba Empat.

Indriyanti, N., Siswandari, \& Ivada, E. (2013) Faktor-Faktor yang Mempengaruhi Minat Melanjutkan Pendidikan ke Perguruan Tinggi pada Siswa Kelas XII Akuntansi SMK Negeri 6 Surakarta. Dalam Jurnal Pendidikan Ekonomi. Hal 111 Surakarta: FKIP Universitas Sebelas Maret. 
Keputusan Menteri Pendidikan Nasional Republik Indonesia Nomor 129a/U/2004 Tentang Standar Pelayanan Minimal Bidang Pendidikan, Standar Pelayanan Minimal (SPM) SMK.

Keputusan Walikota Semarang Nomor 050/716 Tentang Penetapan Warga Miskin Kota Semarang Tahun 2013

Krapp, A (2007) An Educational-Psychological Conceptualisation of Interest. Journal of Commerce Study.

Lea, Susan J dkk (2003) Studies in Higher Education. Dalam Journal of Commerce Study. London: Department of Psychology, University of Plymouth.

Majdi, Udo Yamin Efendi. (2007) Quranic Quotient. Jakarta: Qultum Media.

McManus, I.C., \&Furnham, A (2006) Influences of Education, Background and Personality on Interest and Involvement in the Arts. British Journal of Psychology. London: Department of Psychology, University College London.

Mulyasa (2004) Kurikulum Berbasis Kompetensi. Bandung: PT Remaja Rosdakarya.

Nashori, F. (2003) Potensi-Potensi Manusia. Yogyakarta: Pustaka Pelajar.

Nasution. (2010) Sosiologi Pendidikan. Jakarta: Bumi Aksara.

Nasution, Syafrina \& Tarigan, Lemta. 2011. Pengaruh Sosial Ekonomi Orang Tua terhadap Minat Anak Melanjutkan Pendidikan ke Perguruan Tinggi (Studi Kasus Kelas XI Semester Genap di SMA Sinar Husni Medan Helvetia Kabupaten Deli Serdang Tahun Pelajaran 2010/2011. Dalam Jurnal Citizenship. Hal 1-18 Medan: FIS Universitas Negeri Medan.

Nggermanto, A. (2002) Quantum Quotient. Bandung: Nuansa Cendekia.

Nitisusastro, M (2013) Perilaku Konsumen dalam Perspektif Kewirausahaan. Bandung: Alfabeta.

Papalia, D. E., Old, S. W., \& Feldman, R. D. (2008) Human Development. Jakarta: Kencana.

Prasetyo, B. (2008) Metode Penelitian Kuantitatif. Jakarta: PT Raja Grafindo Persada.

Prawira, P. A (2016) Psikologi Umum. Yogyakarta: Ar-Ruzz Media.

Prihadhi, Endra K (2004) My Potensi. Jakarta: Elek Media Komputindo

Purwanto, N. (2010) Psikologi Pendidikan. Bandung: Remaja Rosdakarya.

Salam, B (2004) Cara Belajar yang Sukses di Perguruan Tinggi. Jakarta: Rineka Cipta.

Sari, W. F.(2015) Pengaruh Pendapatan Orang Tua, Lingkungan Sosial, Potensi Diri, dan Informasi Perguruan Tinggi terhadap Minat Melanjutkan Studi ke Perguruan Tinggi pada Siswa Kelas XII Akuntasi SMK Negeri 1 Kebumen. Skripsi. Semarang: Universitas Negeri Semarang.

Simamora, B (2004) Panduan Riset Perilaku Konsumen. Jakarta: Gramedia Pustaka Utama.

Sutarno (2006) Manajemen Perpustakaan: Suatu Pendekatan Praktik. Jakarta: Sagung Seto.

Slameto (2010) Belajar \& Faktor-Faktor yang Mempengaruhinya. Jakarta: Rineka Cipta.

Sudjana. (2005) Metode Statistika. Bandung: Tarsito.

Sugiharso, Sugiyono, Gunawan, \& Karsono. (2009) Pendidikan Kewarganegaraan. Jakarta: Pusat Perbukuan Departemen Pendidikan Nasional. 
Suharyadi (2013) Statistika untuk Ekonomi dan Keuangan Modern Edisi 2. Jakarta: Salemba Empat.

Sujana. (2014) The Power Of Heart. Jakarta: Zikrul.

Sukardi, D. K (1993) Analisis Inventori Minat dan Kepribadian. Jakarta: Rineka Cipta. Sumakta, I. A. (2015) Pengaruh Prestasi Belajar, Pendapatan Orang Tua, Ekspektasi Kerja Terhadap Minat Melanjutkan Studi ke S2 pada Mahasiswa Pendidikan Ekonomi FE UNY. Skripsi. Yogyakarta: Universitas Negeri Yogyakarta.

Sumardi, M., \& Evers, H. D. (1982) Sumber Pendapatan, Kebutuhan Pokok dan Perilaku Menyimpang. Jakarta: Rajawali.

Syah, M (2008) Psikologi Pendidikan dengan Pendekatan Baru. Bandung: Remaja Rosdakarya.

Syaukani. (2002) Titik Temu dalam Dunia Pendidikan. Jakarta: Nuansa Madani.

Wahyuni, E. N., \& Baharuddin (2007) Teori Belajar Dan Pembelajaran. Yogyakarta: Ar-Ruzz Media.

Wibowo, Hery (200). Fortune Favor the Ready. Bandung: Mata Air Makna.

Wilcox, Paula dkk. (2005) Studies in Higher Education. Dalam Australian Journal of Commerce Study. London: University of Brighton.

Wiyono, S (2006) Manajemen Potensi Diri. Jakarta: Grasindo.

Zhang, Li-fang., \& Postiglione, Gerard A. (2000) Thingking Styles, Self-Esteem, and Socio-Economic Status. Dalam Journal of Education. Hong Kong: Department of Education, The University of Hong Kong 